\title{
Nutrient Accumulation in Amaryllis
}

\author{
Caroline de Moura D'Andréa Mateus ${ }^{1 *}$, Kathia Fernandes Lopes Pivetta ${ }^{2}$, \\ Roberto Lyra Villas Bôas ${ }^{1}$, Regina Maria Monteiro de Castilho ${ }^{3}$, \\ Maria Márcia Pereira Sartori ${ }^{4}$, Renata Bachin Mazzini-Guedes ${ }^{5}$
}

\author{
${ }^{1}$ Department of Soil and Environmental Resources, São Paulo State University (UNESP), Botucatu, Brazil \\ ${ }^{2}$ Department of Crop Production, São Paulo State University (UNESP), Jaboticabal, Brazil \\ ${ }^{3}$ Department of Crop Production, Food Technology, and Socio-Economics, São Paulo State University (UNESP), \\ Ilha Solteira, Brazil \\ ${ }^{4}$ Department of Crop Science, São Paulo State University (UNESP), Botucatu, Brazil \\ ${ }^{5}$ Federal University of Paraná (UFPR), Jandaia do Sul, Brazil \\ Email:*caroline_ma teus@hotmail.com
}

How to cite this paper: Mateus, C. de M.D., Pivetta, K.F.L., Bôas, R.L.V., de Castilho, R.M.M., Sartori, M.M.P. and Mazzini-Guedes, R.B. (2018) Nutrient Accumulation in Amaryllis. American Journal of Plant Sciences, 9, 239-249.

https://doi.org/10.4236/ajps.2018.92020

Received: December 13, 2017

Accepted: January 23, 2018

Published: January 26, 2018

Copyright (c) 2018 by authors and Scientific Research Publishing Inc. This work is licensed under the Creative Commons Attribution International License (CC BY 4.0).

http://creativecommons.org/licenses/by/4.0/

\begin{abstract}
Amaryllis plants (Hippeastrum hybrid, in the family Amaryllidaceae) are cultivated in Brazil mainly for bulb export. Studies about the nutrient accumulation dynamics by the species are yet incipient when considering Brazilian cultivation conditions. The objective was to determine the nutrient accumulation in amaryllis "Orange Souvereign" cultivated in the field. The experimental design was entirely randomized with four replications and 14 collection periods (at 30, 60, 90, 120, 150, 180, 210, 240, 270, 300, 330, 360, 390 , and 420 days after planting). Sampled plants were divided into leaves, bulb, and roots, which were used for determination of nutrient accumulation by leaves (aerial part) and bulb + roots (underground part). Nutrient accumulation of $\mathrm{N}, \mathrm{P}, \mathrm{K}, \mathrm{Ca}, \mathrm{Mg}, \mathrm{S}, \mathrm{B}, \mathrm{Cu}, \mathrm{Fe}, \mathrm{Mn}$, and $\mathrm{Zn}$ was calculated for each collection period, and then represented by curves of macro and micronutrient accumulation, as well as accumulation percentages for each plant part. For most macro and micronutrients, the interval of maximum accumulation fell from 301 to 420 days after planting, matching with the cycle final stage of plants cultivated in the field. Accumulated macronutrients by amaryllis plants along the cultivation cycle was, in g.plant ${ }^{-1}: 1.57$ $\mathrm{N} ; 0.19 \mathrm{P} ; 2.58 \mathrm{~K} ; 0.64 \mathrm{Ca} ; 0.20 \mathrm{Mg}$; and $0.29 \mathrm{~S}$, following the descending order: $\mathrm{K}>\mathrm{N}>\mathrm{Ca}>\mathrm{S}>\mathrm{Mg}>\mathrm{P}$. Accumulated micronutrients, in mg.plant ${ }^{-1}$, was: $2.18 \mathrm{~B} ; 1.17 \mathrm{Cu} ; 22.33 \mathrm{Fe} ; 2.19 \mathrm{Mn}$; and $4.09 \mathrm{Zn}$, following the descending order: $\mathrm{Fe}>\mathrm{Zn}>\mathrm{Mn}>\mathrm{B}>\mathrm{Cu}$.
\end{abstract}

\section{Keywords}

Plant Nutrition, Ornamental Geophytes, Hippeastrum hybrid 


\section{Introduction}

Ornamental bulbous plants are herbaceous species that are morphologically characterized by regeneration structures located in underground storage organs, such as rhizomes, tubers, and bulbs [1]. This plant group is composed of more than 800 geni [2]; one of them, Hippeastrum, is commonly known as amaryllis, lily, or empress flower [3]. Hippeastrum genus, belonging to the family Amaryllidaceae, comprises 70 to 90 species and more than 600 cultivars and hybrids; its origin center is Eastern Brazil [4] that holds 40 native species [5].

Amaryllis inflorescences are terminal, with big flowers, and colors varying with species, hybrid, and variety, but ranging from dark red to white, green, orange, and corresponding mixtures [2] [4] [5]. Amaryllis plants are produced commercially as cut flowers, pot plants, or propagation material (bulb), besides being also used for gardening and landscaping [1]. In Brazil, amaryllis is marketed on a small-scale directly to the retail consumer as cut flowers, pot plants, and single bulbs; on the other hand, it is very much exported as bulbs [6], so most of bulb production is destined to Netherlands [4] [7]. In general, $60 \%$ of the whole production is directed to the international market, while $40 \%$ is consumed in the country as pot plants and cut flowers [6].

Several climatic and plant conditions are necessary to achieve amaryllis satisfactory growth and development. Therefore, physical and nutrition characteristics of the growing medium are fundamental for an economically feasible cultivation [8]. One way to monitor the need of a certain nutrient along plant cycle is the nutrient accumulation curve.

Studies on nutrient accumulation in plant parts are important to quantify nutritional requirements and indicate more appropriate periods for fertilization. The curve of nutrient accumulation usually denotes fertilization according to the physiological stage of maximum absorption, so plants receive the total amount of required nutrients towards maximum production [8]. This results in lower fertilizer losses and toxicity risks [9], with no damage to the environment or the crop.

Mineral nutrients, when considering the essentiality criteria, are equally important for crop production. However, there is a classification based on the rate of nutrient requirement that accumulates in plant dry matter and can be either macronutrients $(\mathrm{N}, \mathrm{P}, \mathrm{K}, \mathrm{Ca}, \mathrm{Mg}$, and $\mathrm{S}$ ) or micronutrients $(\mathrm{B}, \mathrm{Cu}, \mathrm{Fe}, \mathrm{Mn}$ and Zn) [10].

In Brazil, research on mineral nutrition for floriculture and ornamental plants are recent and highlight only few species. Therefore, our objective was to determine the nutrient accumulation (macro and micronutrients) in amaryllis (Hippeastrum hybrid "Orange Souvereign") along its cultivation cycle under field conditions.

\section{Material and Methods}

The experiment was conducted under field conditions at a commercial area of 
bulb production for exportation, located in Santo Antonio de Posse, Sao Paulo State, Brazil $\left(22^{\circ} 42^{\prime} 24^{\prime \prime} S, 47^{\circ} 59^{\prime} 50^{\prime \prime} \mathrm{W}\right)$. The climate in the region, according to the Köppen classification, is of Cwa type-subtropical with hot summers.

Planting was performed in a soil with the following characteristics at $0.0-20.0$ cm depth: pH 6.0 (water); O.M. = $3.6 \mathrm{dag} \cdot \mathrm{kg}^{-1} ; \mathrm{P}=71 \mathrm{mg} \cdot \mathrm{dm}^{-3} ; \mathrm{K}=0.46$ $\mathrm{cmol}_{c} \cdot \mathrm{dm}^{-3} ; \mathrm{Ca}=4.5 \mathrm{cmol}_{c} \cdot \mathrm{dm}^{-3} ; \mathrm{Mg}=1.4 \mathrm{cmol}_{c} \cdot \mathrm{dm}^{-3} ; \mathrm{CEC}=9.0 \mathrm{cmol}_{c} \cdot \mathrm{dm}^{-3}$; $\mathrm{V} \%=71 ; \mathrm{S}=6.0 \mathrm{mg} \cdot \mathrm{dm}^{-3} ; \mathrm{Na}=4.0 \mathrm{mg} \cdot \mathrm{dm}^{-3} ; \mathrm{B}=0.2 \mathrm{mg} \cdot \mathrm{dm}^{-3} ; \mathrm{Fe}=80 \mathrm{mg} \cdot \mathrm{dm}^{-3} ;$ $\mathrm{Mn}=5.8 \mathrm{mg} \cdot \mathrm{dm}^{-3} ; \mathrm{Cu}=2.5 \mathrm{mg} \cdot \mathrm{dm}^{-3} ;$ and $\mathrm{Zn}=19 \mathrm{mg} \cdot \mathrm{dm}^{-3}$. Due to $\mathrm{N}$ movement along soil profile, there is no correlation, considering Brazilian conditions, between inorganic $\mathrm{N}$ content and crop yield; therefore, such element is not considered for basic soil analysis.

Spacing among rows was of $0.10 \mathrm{~m}$, reaching the density of 40 seedlings $\cdot \mathrm{m}^{-2}$. Each plant bed was $1.25 \mathrm{~m}$ width and $0.20 \mathrm{~m}$ height. Seedlings were prepared following the twin-scale propagation method and planted with 5.0 to $10.0 \mathrm{~cm}$ height (from the upper bulb part up to the leaf end). The variety used was "Orange Souvereign" that produces red-orange flowers, which plant cycle is from February (planting) to next year's May (harvest). Amaryllis plants were cultivated for bulb commercialization, not for cut flowers. Therefore, plants were harvested before flowering.

The experimental design was entirely randomized with 14 harvest periods (30, $60,90,120,150,180,210,240,270,300,330,360,390$, and 420 days after planting of twin scales) and four replications. For each harvest, 10 plants per replication were randomly sampled from a 2-hectare area.

The applied agricultural practices related to pest, disease and weed control were those commonly administered. Therefore, all those cultivation operations necessary for crop development were implemented, including soil coverage with sugarcane bagasse with the aim to maintain soil temperature and moisture. Irrigation was performed by the sprinkler method, so the provided water amount varied with plant growth speed and soil water content; however, the soil surface layer was always moist.

Considering the results of soil analysis, liming was performed one month before planting with the aim to rise the base saturation to $75 \%$. Fertilization was done at planting and as top-dressing (solid fertilization, fertigation, and foliar fertilization). The applied total amount of each nutrient along the entire amaryllis production cycle, in $\mathrm{kg} \cdot \mathrm{ha}^{-1}$, was: $1247.1 \mathrm{~N} ; 139.0 \mathrm{P} ; 1757.7 \mathrm{~K}$; $1391.3 \mathrm{Ca}$; 437.2 Mg; 613.1 S; 5.1 B; 19.2 Cu; 0.1 Fe; 26.7 Mn; 24.7 Zn; 87.3 Si; and 0.1 Mo.

After each harvest period, plants were divided into leaves (aerial part) and bulb + roots (underground part), washed, and dried in a forced ventilation heater at $65^{\circ} \mathrm{C}$ for 48 hours. Dry matter of leaves and bulb + roots were weighted on a digital scale of $0.01 \mathrm{~g}$ accuracy. For evaluation of plant nutritional status, chemical analysis of each plant part (leaves, bulbs, and roots) were performed for determination of macronutrients $(\mathrm{N}, \mathrm{P}, \mathrm{K}, \mathrm{Ca}, \mathrm{Mg}$, and $\mathrm{S})$ and micronutrients ( $\mathrm{B}, \mathrm{Cu}, \mathrm{Fe}, \mathrm{Mn}$, and $\mathrm{Zn})[11]$. Macronutrients and micronutrients accu- 
mulation (in g.plant ${ }^{-1}$ and $\mathrm{mg} \cdot$ plant $^{-1}$, respectively) was then calculated from data of plant dry matter and nutrient concentration.

Linear correlation between total plant dry matter and accumulated macro and micronutrients was calculated according to Pearson method.

Regression curves of nutrient accumulation (macro and micronutrients) according to days after planting were adjusted with the help of Origin $2016^{\circledR}$ software [12] for sigmoidal Boltzmann equation $\left(Y=A 2+\frac{A 1-A 2}{\left(1+\mathrm{e}^{((x-x 0) / d x)}\right)}\right)$, where:

$Y=$ amount of accumulated nutrients, in g.plant ${ }^{-1}$ for macronutrients and $\mathrm{mg} \cdot$ plant $^{-1}$ for micronutrients, which was obtained according to the harvest periods;

$\mathrm{x}=$ upper limit of the sampling period, in days;

$A 1=$ minimum nutrient accumulation, in $\mathrm{g} \cdot \mathrm{plant}^{-1}$ for macronutrients and $\mathrm{mg} \cdot$ plant $^{-1}$ for micronutrients;

$A 2=$ maximum nutrient accumulation, in g.plant ${ }^{-1}$ for macronutrients and $\mathrm{mg} \cdot$ plant $^{-1}$ for micronutrients;

$A 1-A 2=$ loss of the accumulated nutrient amount, in $\mathrm{g} \cdot$ plant $^{-1}$ for macronutrients and mg.plant ${ }^{-1}$ for micronutrients;

$x 0=$ upper limit of the sampling period that corresponds to the intermediate value between maximum and minimum amount of accumulated nutrients;

$d x=$ parameter indicating speed of gain or loss of nutrient accumulation (tangent at $x 0$ value).

\section{Results and Discussion}

Results are presented separately for leaves and bulb + roots because bulbs are marketed with roots, while leaves remain at the cultivation area, replacing part of the nutrients in the soil.

At 420 DAP (days after planting), greater amount of dry matter was located in the bulb + roots $(52.3 \%)$, while leaves retained the remaining (47.6\%) (Table 1). Gladiolus plants (Gladiolus grandiflorus), which are also bulbous species, had, at the end of plant cycle after flowering, the following dry matter distribution: $44.9 \%$ in the aerial part (leaves + flower stem) and $55.1 \%$ in the corm + cormels (disregarding the root dry matter) [13].

Average dry matter distribution was: $10.2 \%$ up to $210 \mathrm{DAP}$, that is, period referring to half of the cultivation cycle; $50.0 \%$ up to 330 DAP; and $86.2 \%$ up to 390 DAP (Table 1), showing that $50.0 \%$ of plant dry matter is accumulated after 330 DAP, combined with most of macro and micronutrients. Virtually, there was no dry matter accumulation by plants from 120 to 150 DAP.

There were high positive correlations between total plant dry matter and accumulated amount of all macro and micronutrients in amaryllis: $r=0.9929$ for $\mathrm{N} ; \mathrm{r}$ $=0.9942$ for $\mathrm{P} ; \mathrm{r}=0.9965$ for $\mathrm{K} ; \mathrm{r}=0.9929$ for $\mathrm{Ca} ; \mathrm{r}=0.9767$ for $\mathrm{Mg} ; \mathrm{r}=0.9981$ for $\mathrm{S} ; \mathrm{r}=0.9761$ for $\mathrm{B} ; \mathrm{r}=0.9976$ for $\mathrm{Cu} ; \mathrm{r}=0.9853$ for $\mathrm{Fe} ; \mathrm{r}=0.9916$ for $\mathrm{Mn}$; 
Table 1. Bulb diameter, dry matter of leaves and bulb + roots, and total plant dry matter (TPDM) of Hippeastrum hybrid "Orange Souvereign" cultivated under field conditions according to days after planting (DAP).

\begin{tabular}{cccccccc}
\hline $\begin{array}{c}\text { Days after } \\
\text { planting }\end{array}$ & $\begin{array}{c}\text { Bulb } \\
\text { diameter }\end{array}$ & \multicolumn{2}{c}{ Total plant dry mass } & Dry matter of leaves & \multicolumn{2}{c}{$\begin{array}{c}\text { Dry matter of } \\
\text { bulb + roots }\end{array}$} \\
\hline cm & g & $\begin{array}{c}\text { \% regarding } \\
\text { DAP }\end{array}$ & g & $\begin{array}{c}\text { \% regarding } \\
\text { TPDM }\end{array}$ & g & $\begin{array}{c}\text { \% regarding } \\
\text { TPDM }\end{array}$ \\
\hline 30 & 1.19 & 0.50 & 0.6 & 0.00 & 0.0 & 0.50 & 100.0 \\
60 & 1.38 & 0.56 & 0.7 & 0.11 & 19.6 & 0.45 & 80.4 \\
90 & 1.86 & 2.16 & 2.5 & 0.43 & 19.9 & 1.73 & 80.1 \\
120 & 2.31 & 2.16 & 2.5 & 0.89 & 41.2 & 1.27 & 58.8 \\
150 & 2.96 & 4.65 & 5.4 & 1.86 & 40.0 & 2.79 & 60.0 \\
180 & 3.15 & 6.14 & 7.2 & 2.80 & 45.6 & 3.34 & 54.4 \\
210 & 3.39 & 8.76 & 10.2 & 4.28 & 48.9 & 4.48 & 51.1 \\
240 & 4.24 & 16.01 & 18.7 & 8.88 & 55.5 & 7.13 & 44.5 \\
270 & 4.86 & 21.49 & 25.1 & 12.57 & 58.5 & 8.92 & 41.5 \\
300 & 5.73 & 31.06 & 36.3 & 18.54 & 59.7 & 12.52 & 40.3 \\
330 & 7.06 & 42.76 & 50.0 & 24.49 & 57.3 & 18.27 & 42.7 \\
360 & 8.24 & 67.14 & 78.5 & 31.98 & 47.6 & 35.16 & 52.4 \\
390 & 8.90 & 73.78 & 86.2 & 31.74 & 43.0 & 42.04 & 57.0 \\
420 & 9.11 & 85.57 & 100.0 & 40.72 & 47.6 & 44.75 & 52.3 \\
\hline
\end{tabular}

and $r=0.9989$ for $\mathrm{Zn}$. This demonstrates that all nutrients are required along plant cycle with an increasing demand according to plant development.

Bulb mean diameter at the end of cultivation was $9.1 \mathrm{~cm}$, which is bigger than what was found by [14] for Hippeastrum vittatum cultivated in different substrates with varied NPK doses; greater bulb diameter $(7.99 \mathrm{~cm})$ was obtained with the highest NPK dose, which was 5 g.plant $^{-1}$ of NPK 19-19-19 applied monthly via fertigation in a substrate mixture of sand and leaf compost. Other authors found values of bulb diameter close to $9 \mathrm{~cm}$ when studying different media substrates on twin scale cutting propagation [15] and close to $8 \mathrm{~cm}$ when studying the response in bulb growth of Hippeastrum bulbs of two initial sizes to $\mathrm{N}$ and $\mathrm{K}$ concentration and gaseous $\mathrm{CO}_{2}$ enrichment [16].

After evaluation of plant dry matter and nutrient concentration, amount of accumulated macro (N, P, K, Ca, Mg, and S) and micronutrients (B, Cu, Fe, Mn, and $\mathrm{Zn}$ ) was calculated along its 420-day amaryllis cultivation cycle (Figure 1 and Figure 2).

Results of regression analysis for data of nutrient accumulation in amaryllis "Orange Souvereign" according to its cultivation cycle are shown in Table 2. Values of $x 0$ represent the moment that plants most require nutrients, reducing such demand after it; these values show then a change on absorption metabolism and nutrient accumulation. Along the 420-day amaryllis cultivation cycle, some $x 0$ values are high for $\mathrm{N}, \mathrm{P}$, and $\mathrm{B}$ (Table 2). Such behavior is observed for these 


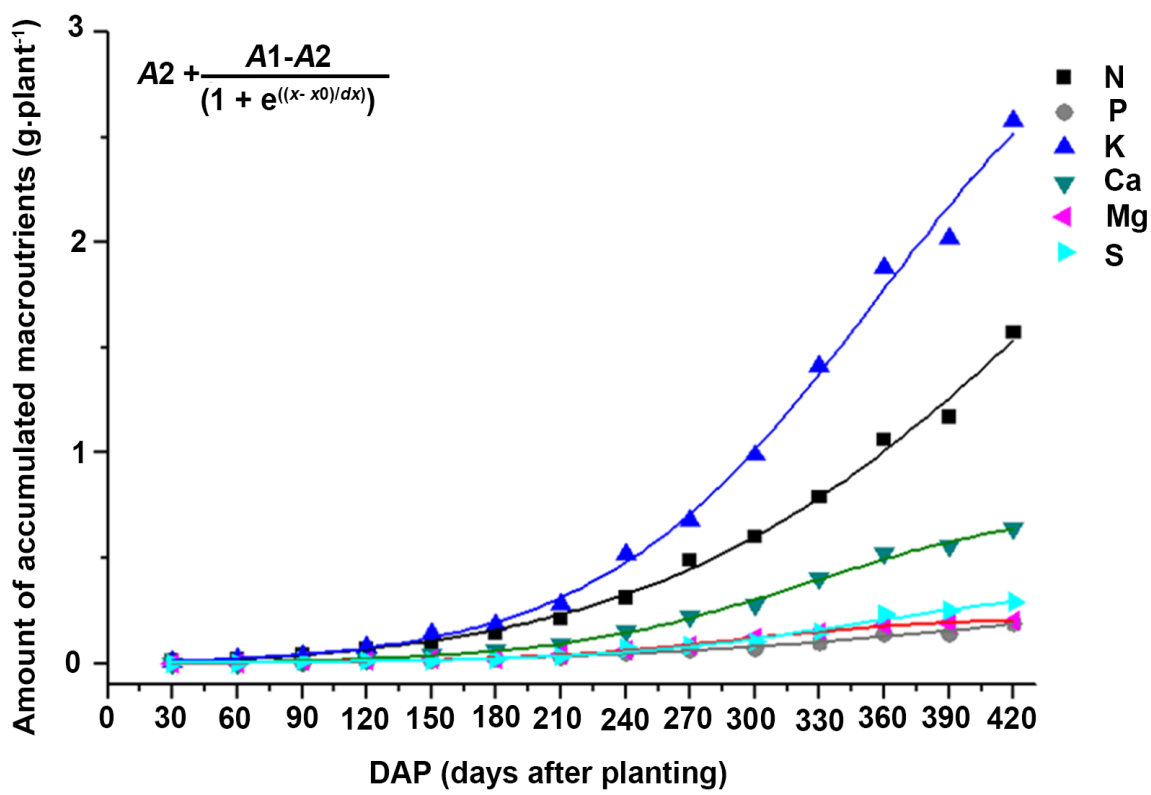

Figure 1. Amount of accumulated macronutrients in Hippeastrum hybrid "Orange Souvereign" along a 420-day cultivation cycle.

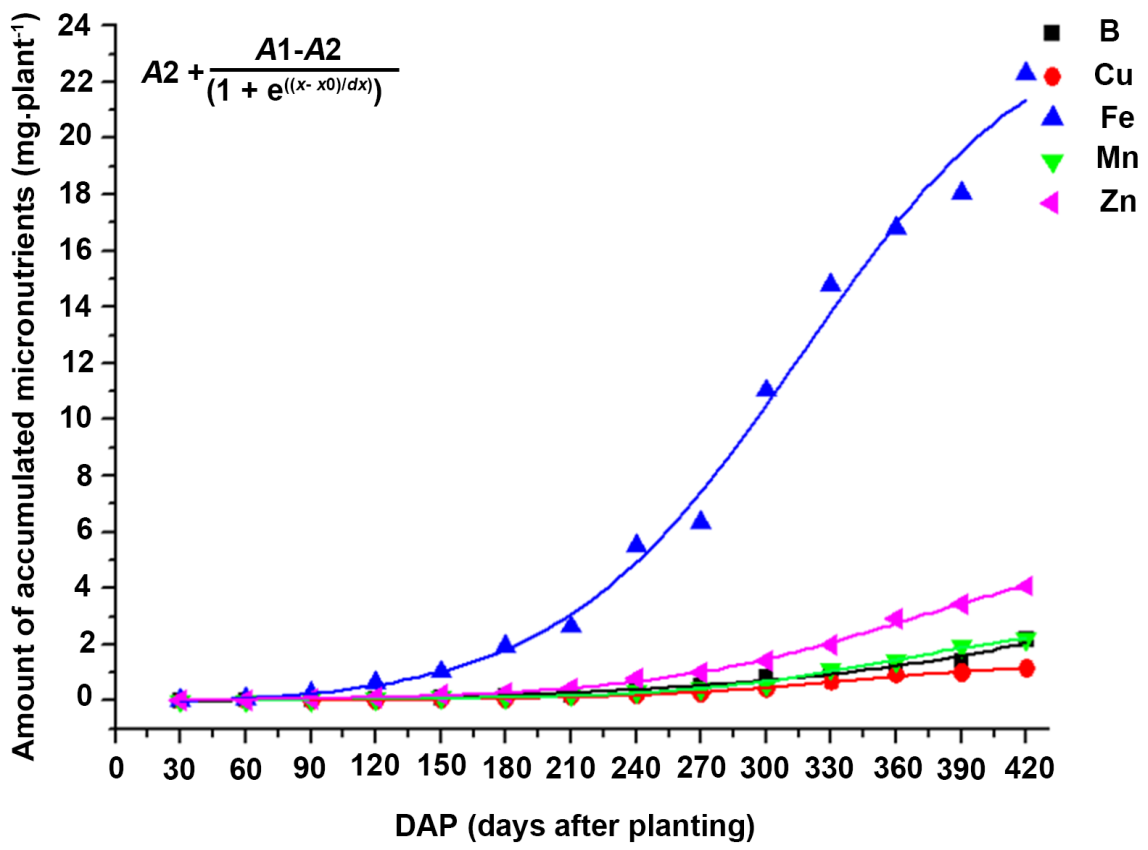

Figure 2. Amount of accumulated micronutrients in Hippeastrum hybrid "Orange Souvereign" along a 420-day cultivation cycle.

nutrients because the species was cultivated for bulb commercialization, thus, it has its development cycle interrupted. If the cycle is continued, $\mathrm{N}$ and $\mathrm{P}$ would be less needed only after 439 days of planting; also, there would be a reduction in $B$ demand around 1200 days after planting. The other nutrients had a decreasing requirement up to 370 days of planting, period within the 420-day amaryllis cultivation cycle for bulb commercialization. 
Table 2. Values resulted from the sigmoidal Boltzmann equation adjusted for macro and micronutrient accumulation curves along the cultivation cycle of Hippeastrum hybrid "Orange Souvereign", and the adjustment determination coefficient.

\begin{tabular}{cccccc}
\hline \multirow{2}{*}{ Nutrient } & \multicolumn{5}{c}{ Values from the sigmoidal Boltzmann equation } \\
\cline { 2 - 6 } & $A 1$ & $A 2$ & $x 0$ & $d \mathrm{x}$ & $I^{2}$ \\
\hline $\mathrm{N}$ & -0.04469 & 3.48566 & 439.78496 & 93.29650 & 0.99389 \\
$\mathrm{P}$ & -0.01066 & 0.42221 & 439.41001 & 102.51306 & 0.98493 \\
$\mathrm{~K}$ & -0.01334 & 3.42691 & 354.47586 & 63.90702 & 0.99429 \\
$\mathrm{Ca}$ & -0.00319 & 0.76275 & 323.92933 & 58.47698 & 0.99701 \\
$\mathrm{Mg}$ & 0.00375 & 0.21669 & 291.30331 & 49.05847 & 0.99667 \\
$\mathrm{~S}$ & 0.00136 & 0.37501 & 347.27905 & 57.64440 & 0.98798 \\
$\mathrm{~B}$ & -0.11937 & 1066.23180 & 1196.29819 & 125.55619 & 0.97741 \\
$\mathrm{Cu}$ & 0.02641 & 1.38636 & 336.54024 & 50.49210 & 0.98819 \\
$\mathrm{Fe}$ & -0.16752 & 24.70437 & 315.59721 & 55.74993 & 0.99013 \\
$\mathrm{Mn}$ & 0.04567 & 2.83715 & 357.48608 & 49.23191 & 0.99234 \\
$\mathrm{Zn}$ & 0.00956 & 5.93737 & 369.03956 & 63.23130 & 0.99664 \\
\hline
\end{tabular}

Higher potassium accumulation in corms + cormels $\left(0.85 \mathrm{~g} \cdot\right.$ plant $\left.^{-1}\right)$ and leaves (0.31 g.plant $\left.{ }^{-1}\right)$ were observed with chemical and organic (urban waste compost) fertilization on gladiolus nutrition [13]. According to Table 3, amaryllis bulbs and leaves absorb and accumulate more macronutrients than gladiolus plants; however, potassium was also the most accumulated macronutrient, both in bulb + roots and leaves. Therefore, for both species (amaryllis and gladiolus), potassium is the most absorbed and accumulated nutrient in all studied plant parts (leaves and bulbs).

Potassium is an enzymatic activating element; it does not belong to the prosthetic group, but it is necessary for enzymatic activity, so more than 50 enzymes are stimulated by this element [10]. Potassium also participates in nutrient translocation and composts for plant drains, such as reserve organs. In comparison with other macronutrients, there is higher potassium accumulation in bulbous species because their bulbs are reserve structures.

Regarding micronutrients, Fe was the most accumulated in leaves, bulb + roots, and in the whole plant (Table 3). This nutrient constitutes enzymes and is part of the prosthetic group, so it is necessary for enzymatic activity [10]. Main roles of micronutrients, with the exception of $\mathrm{B}$ and $\mathrm{Cl}$, are to compose prosthetic groups of metal-proteins and act as activators of enzymatic functions [17].

The accumulation of $\mathrm{B}, \mathrm{Cu}, \mathrm{Fe}, \mathrm{Mn}$, and $\mathrm{Zn}$ in gladioli was determined according to plant age and parts, and Fe was the most accumulated micronutrient [18]. The authors also state that for all studied nutrients, regardless plant age and part, highest accumulation occurred at the end of the development cycle, as we also verified for amaryllis plants. 
Table 3. Amount and percentage of macro and micronutrients accumulated in Hippeastrum hybrid "Orange Souvereign" (total plant, leaves, and bulb + roots) at the end of its cultivation cycle.

\begin{tabular}{|c|c|c|c|c|c|}
\hline \multirow[b]{3}{*}{ Macronutrient } & \multicolumn{5}{|c|}{ Amount and percentage of nutrients } \\
\hline & \multirow{2}{*}{$\begin{array}{c}\text { Total plant } \\
\text { g.plant }{ }^{-1}\end{array}$} & \multicolumn{2}{|c|}{ Leaves } & \multicolumn{2}{|c|}{ Bulb + roots } \\
\hline & & g.plant ${ }^{-1}$ & $\%$ & g.plant ${ }^{-1}$ & $\%$ \\
\hline $\mathrm{N}$ & 1.57 & 0.74 & 47.3 & 0.83 & 52.7 \\
\hline $\mathrm{P}$ & 0.19 & 0.09 & 46.7 & 0.10 & 53.3 \\
\hline $\mathrm{K}$ & 2.58 & 1.62 & 62.8 & 0.96 & 37.2 \\
\hline $\mathrm{Ca}$ & 0.64 & 0.32 & 49.4 & 0.32 & 50.6 \\
\hline $\mathrm{Mg}$ & 0.20 & 0.09 & 48.3 & 0.11 & 51.7 \\
\hline S & 0.29 & 0.10 & 34.7 & 0.19 & 65.3 \\
\hline Micronutrient & $\mathrm{mg} \cdot$ plant $^{-1}$ & mg.plant ${ }^{-1}$ & $\%$ & mg.plant ${ }^{-1}$ & $\%$ \\
\hline B & 2.18 & 1.13 & 51.6 & 1.06 & 48.4 \\
\hline $\mathrm{Cu}$ & 1.17 & 0.60 & 51.8 & 0.56 & 48.2 \\
\hline $\mathrm{Fe}$ & 22.33 & 18.72 & 83.8 & 3.61 & 16.2 \\
\hline $\mathrm{Mn}$ & 2.19 & 1.21 & 55.1 & 0.98 & 44.9 \\
\hline $\mathrm{Zn}$ & 6.26 & 2.16 & 34.6 & 4.09 & 65.4 \\
\hline
\end{tabular}

Amaryllis has a low nutrient requirement at initial stages, therefore, high nutrient levels should be avoided mainly at planting time [4]. In fact, amount of accumulated nutrients, with the exception of $\mathrm{Mg}$, was higher at the end of the cultivation cycle, from 301 to 420 DAP (Table 4). In general, macronutrient accumulation presented a mean of $6.4 \%$ up to 150 DAP, $35.8 \%$ from 151 to 300 DAP, and $57.7 \%$ from 301 to 420 DAP; for micronutrients, there was an accumulation mean of $5.6 \%$ up to $150 \mathrm{DAP}, 31.3 \%$ from 151 to $300 \mathrm{DAP}$, and $63.1 \%$ from 301 to 420 DAP (Table 4). Therefore, greater supply of macro and micronutrients is needed at the last 120 days of amaryllis cultivation.

From all nutrients accumulated by amaryllis (Table 5), $\mathrm{K}$ was the most accumulated macronutrient $\left(1033.2 \mathrm{~kg} \cdot \mathrm{ha}^{-1}\right)$ along the plant cultivation cycle, followed by $\mathrm{N}, \mathrm{Ca}, \mathrm{S}, \mathrm{Mg}$, and P. The most accumulated micronutrient was $\mathrm{Fe}(8.9$ $\mathrm{kg} \cdot \mathrm{ha}^{-1}$ ), followed by $\mathrm{Zn}, \mathrm{Mn}, \mathrm{B}$, and $\mathrm{Cu}$. From the total applied of each nutrient per hectare, plants used the following percentage: $50.2 \% \mathrm{~N} ; 53.3 \% \mathrm{P} ; 58.8 \% \mathrm{~K}$; $18.1 \% \mathrm{Ca} ; 18.1 \% \mathrm{Mg} ; 19.1 \% \mathrm{~S} ; 17.3 \% \mathrm{~B} ; 2.4 \% \mathrm{Cu} ; 3.3 \% \mathrm{Mn}$; and $6.6 \% \mathrm{Zn}$.

The comparison among accumulation values of macro and micronutrients in bulb + roots (Table 3 ) and the total accumulated amount along the entire amaryllis cultivation cycle (Table 5) indicates that the following quantities of each nutrient were exported from the cultivation area with bulb + roots at harvest time, in $\mathrm{kg} \cdot \mathrm{ha}^{-1}$ : $330.20 \mathrm{~N} ; 39.44 \mathrm{P} ; 384.35 \mathrm{~K} ; 129.38 \mathrm{Ca} ; 40.84 \mathrm{Mg} ; 76.27 \mathrm{~S} ; 0.44$ B; $0.24 \mathrm{Cu} ; 1.44 \mathrm{Fe} ; 0.40 \mathrm{Mn}$; and $1.05 \mathrm{Zn}$.

Fertilization applied along the 420 -day cultivation cycle, at a commercial area of bulb production for exportation, reached the production goal, as bulbs had 9 
Table 4. Amount and percentage of macro and micronutrients accumulated in Hippeastrum hybrid "Orange Souvereign" according to specific periods of a 420-day cultivation cycle.

\begin{tabular}{|c|c|c|c|c|c|c|}
\hline \multirow[b]{3}{*}{ Macronutrient } & \multicolumn{6}{|c|}{ Days after planting } \\
\hline & \multicolumn{2}{|c|}{ up to 150} & \multicolumn{2}{|c|}{151 to 300} & \multicolumn{2}{|c|}{301 to 420} \\
\hline & g.plant ${ }^{-1}$ & $\%$ & g.plant ${ }^{-1}$ & $\%$ & g.plant ${ }^{-1}$ & $\%$ \\
\hline $\mathrm{N}$ & 0.10 & 6.3 & 0.51 & 32.2 & 0.96 & 61.5 \\
\hline $\mathrm{P}$ & 0.01 & 7.0 & 0.07 & 33.3 & 0.11 & 59.7 \\
\hline $\mathrm{K}$ & 0.13 & 5.2 & 0.86 & 33.2 & 1.59 & 61.6 \\
\hline $\mathrm{Ca}$ & 0.04 & 6.4 & 0.24 & 37.6 & 0.36 & 56.0 \\
\hline $\mathrm{Mg}$ & 0.02 & 8.9 & 0.10 & 50.5 & 0.08 & 40.6 \\
\hline S & 0.01 & 4.9 & 0.09 & 28.1 & 0.19 & 67.0 \\
\hline Micronutrient & mg.plant ${ }^{-1}$ & $\%$ & mg.plant ${ }^{-1}$ & $\%$ & mg.plant ${ }^{-1}$ & $\%$ \\
\hline B & 0.11 & 5.2 & 0.73 & 33.5 & 1.34 & 61.3 \\
\hline $\mathrm{Cu}$ & 0.09 & 7.4 & 0.32 & 27.8 & 0.75 & 64.8 \\
\hline $\mathrm{Fe}$ & 1.04 & 4.7 & 10.00 & 44.7 & 11.30 & 50.6 \\
\hline $\mathrm{Mn}$ & 0.12 & 5.6 & 0.46 & 20.9 & 1.61 & 73.5 \\
\hline $\mathrm{Zn}$ & 0.21 & 5.1 & 1.22 & 29.8 & 2.67 & 65.1 \\
\hline
\end{tabular}

Table 5. Total nutrient amount accumulated in Hippeastrum hybrid "Orange Souvereign" along a 420-day cultivation cycle.

\begin{tabular}{cc}
\hline Nutrient & Accumulated amount $\left(\mathrm{kg} \cdot \mathrm{ha}^{-1}\right)$ \\
$\mathrm{N}$ & 626.5 \\
$\mathrm{P}$ & 74.0 \\
$\mathrm{~K}$ & $1,033.2$ \\
$\mathrm{Ca}$ & 255.7 \\
$\mathrm{Mg}$ & 79.0 \\
$\mathrm{~S}$ & 116.8 \\
$\mathrm{~B}$ & 0.9 \\
$\mathrm{Cu}$ & 0.5 \\
$\mathrm{Fe}$ & 8.9 \\
$\mathrm{Mn}$ & 0.9 \\
$\mathrm{Zn}$ & 1.6 \\
\hline
\end{tabular}

$\mathrm{cm}$ diameter (Table 1), size considered commercially appropriate for the amaryllis variety "Orange Souvereign". However, according to the percentage of each nutrient applied via fertilization and used by plants, it is still possible to proceed with adjustment of both nutrient amount and application time with the aim to optimize production and avoid damage to the environment. 


\section{Conclusions}

Amount of macronutrients accumulated by amaryllis plants (Hippeastrum hybrid "Orange Souvereign") along the cultivation cycle, in g.plant ${ }^{-1}$, was: $1.57 \mathrm{~N}$; $0.19 \mathrm{P} ; 2.58 \mathrm{~K} ; 0.64 \mathrm{Ca} ; 0.20 \mathrm{Mg}$; and 0.29 S, following the descending order: $\mathrm{K}$ > $\mathrm{N}>\mathrm{Ca}>\mathrm{S}>\mathrm{Mg}>\mathrm{P}$.

Amount of micronutrients accumulated by amaryllis plants along the cultivation cycle, in mg.plant ${ }^{-1}$, was: $2.18 \mathrm{~B} ; 1.17 \mathrm{Cu} ; 22.33 \mathrm{Fe}$; $2.19 \mathrm{Mn}$; and $4.09 \mathrm{Zn}$, following the descending order: $\mathrm{Fe}>\mathrm{Zn}>\mathrm{Mn}>\mathrm{B}>\mathrm{Cu}$.

For most of macro and micronutrients, maximum accumulation interval ranged from 301 to 420 days after planting, that is, occurred at the final stage of amaryllis cultivation cycle.

\section{References}

[1] Kamenetsky, R. and Okubo, H. (2013) Ornamental Geophytes: From Basic Science to Sustainable Production. CRC Press, New York.

[2] Lorenzi, H. and Souza, H.M. (2013) Plantas para Jardim no Brasil: Herbáceas, Arbustivas e Trepadeiras. Instituto Plantarum, Nova Odessa.

[3] Pacific Bulb Society (2015) Hippeastrum. http://www.pacificbulbsociety.org/pbswiki/index.php/Hippeastrum

[4] Tombolato, A.F.C. (2004) Cultivo Comercial de Plantas Ornamentais. Instituto Agronômico, Campinas.

[5] Tombolato, A.F.C. and Matthes, L.A.F. (1998) Collection of Hippeastrum spp., Alstroemeria spp. and Other Brazilian Bulbous Species. Acta Horticulturae, 454, 91-98. https://doi.org/10.17660/ActaHortic.1998.454.9

[6] Tombolato, A.F.C., Uzzo, R.P., Junqueira, A.H., Peetz, M.S., Stancato, G.C. andAlexandre, M.A.V. (2010) Bulbosas Ornamentais no Brasil. Revista Brasileira de Horticultura Ornamental, 16, 127-138. https://doi.org/10.14295/rbho.v16i2.553

[7] Junqueira, A.H. (2013) Balanço do comércio exterior da floricultura brasileira. http://www.hortica.com.br/artigos/2014/2013_Comercio_Exterior_Floricultura.pdf

[8] Pedrosa, M.W., Barbosa, J.G., Martínez, H.P. and Cardoso, A.A. (2000) Concentração e Acúmulo de Nutrientes em Plantas de Gypsophila paniculata L. Cultivadas em Solução Nutritiva. Revista Brasileira Horticultura Ornamental, 6, 19-30.

[9] Camargo, M.S., Shimizu, L.K., Saito, M.A., Kameoka, C.H., Mello, S.C. and Carmello, Q.A.C. (2004) Crescimento e Absorção de Nutrientes pelo Lisianthus (Eustoma grandiflorum) Cultivado em Solo. Horticultura Brasileira, 22, 143-146. https://doi.org/10.1590/S0102-05362004000100030

[10] Malavolta, E. (2006) Manual de Nutrição Mineral de Plantas. Agronômica Ceres, São Paulo.

[11] Malavolta, E., Vitti, G.C. and Oliveira, S.A. (1997) Avaliação do Estado Nutricional das Plantas: Princípios e Aplicações. Potafos, Piracicaba.

[12] Originlab Corporation (2015) Origin 2016. http://www.originlab.com

[13] Ruppenthal, V. and Castro, A.M.C. (2005) Efeito do Composto de Lixo Urbano na Nutrição e Produção de Gladíolo. Revista Brasileira de Ciência do Solo, 29, 145-150. https://doi.org/10.1590/S0100-06832005000100016

[14] El-naggar, A.H. and El-nasharty, A.B. (2009) Effect of Growing Media and Mineral 
Fertilization on Growth, Flowering, Bulbs Productivity and Chemical Constituents of Hippeastrum vittatum, Herb. American-Eurasian Journal of Agricultural \& Environmental Sciences, 6, 360-371.

[15] Zhanga, W., Songb, L., Silva, J.A.T. and Suna, H. (2013) Effects of Temperature, Plant Growth Regulators and Substrates and Changes in Carbohydrate Content during Bulblet Formation by Twin Scale Propagation in Hippeastrum vittatum "Red lion”. Scientia Horticulturae, 160, 230-237.

https://doi.org/10.1016/j.scienta.2013.06.001

[16] Silberbush, M., Ephrath, J.E., Alekperov, Ch. and Ben-Asher, J. (2003) Nitrogen and Potassium Fertilization Interactions with Carbon Dioxide Enrichment in Hippeastrum Bulb Growth. Scientia Horticulturae, 98, 85-90.

https://doi.org/10.1016/S0304-4238(02)00205-4

[17] Gupta, U.C. (2001) Micronutrientes e Elementos Tóxicos em Plantas e Animais. In: Ferreira, M.E., Cruz, M.C.P., Raij, B.V. and Abreu, C.A., Eds., Micronutrientes e Elementos Tóxicos na Agricultura, POTAFOS/CNPq/FAPESP, Jaboticabal, 13-41.

[18] Haag, H.P., Oliveira, G.D. and Mattos, J.R. (1970) Absorção de nutrientes pela planta do gladíolo. Anais da Escola Superior de Agricultura Luiz de Queiroz, 27, 125-141. https://doi.org/10.1590/S0071-12761970000100009 